\title{
From molecules to neural morphology: understanding neuroinflammation in autism spectrum condition
}

\author{
Adam M. H. Young ${ }^{1,2^{*}}$, Bhismadev Chakrabarti ${ }^{1,3}$, David Roberts ${ }^{2}$, Meng-Chuan Lai ${ }^{1,4,5}$, John Suckling ${ }^{6,7}$ \\ and Simon Baron-Cohen ${ }^{1,8}$
}

\begin{abstract}
Growing evidence points toward a critical role for early (prenatal) atypical neurodevelopmental processes in the aetiology of autism spectrum condition (ASC). One such process that could impact early neural development is inflammation. We review the evidence for atypical expression of molecular markers in the amniotic fluid, serum, cerebrospinal fluid (CSF), and the brain parenchyma that suggest a role for inflammation in the emergence of ASC. This is complemented with a number of neuroimaging and neuropathological studies describing microglial activation. Implications for treatment are discussed.
\end{abstract}

Keywords: NF-KB, Autism, Brain, Inflammation

\section{Background}

The presence of inflammation in autism spectrum condition (ASC) is a concept that is gathering momentum. Traditionally, different forms of ASC have been recognised: Classic (or Kanner type) autism (which can entail general intellectual disability and language delay), Asperger syndrome (which entails no developmental language delay or intellectual disability) and syndromic forms of autism such as co-occurring with Rett syndrome, Fragile $\mathrm{X}$ syndrome, tuberous sclerosis complex and Timothy's syndrome, to name a few [29]. In DSM-5, these are now subsumed under a single umbrella term of autism spectrum disorder (ASD). In this article, we use the term autism spectrum condition (ASC) because the term 'disorder' is regarded by some as stigmatising and the term 'condition' acknowledges both the disability and the differences and strengths in such individuals.

The key behavioural features defining ASC are the presence of difficulties in social reciprocity and communication, alongside unusually narrow interests, repetitive

\footnotetext{
*Correspondence: ay276@cam.ac.uk

'Autism Research Centre, Department of Psychiatry, University of Cambridge, Douglas House, 18B Trumpington Road, Cambridge, UK

${ }^{2}$ School of Clinical Medicine, Addenbrookes Hospital, University of Cambridge, Cambridge, UK

Full list of author information is available at the end of the article
}

behaviours and speech, insistence on sameness, and idiosyncratic sensory responses DSM-V ${ }^{\bullet}$ [30]. Cognitively, ASC is described as a condition characterised by weakened central coherence [35, 46], executive dysfunction [76], and mentalising difficulties [5, 6] alongside strengths in 'systemizing' [5] and attention to detail [82, 83]. Genetic, environmental, neurological, and immunological factors contribute to its aetiology [72].

Some, but not all, studies suggest that ASC involves early brain overgrowth $[21,74]$. This is unlikely to be a universal phenomenon $[17,73]$ and is one of the key factors that could be linked to the heterogeneity of the condition together with neuroinflammation. Nevertheless, there are a multitude of developmental reasons which could be responsible for this observation, including atypical pruning of synapses [41] and, more recently, neuron density has been shown to play a significant role [22], but this could also reflect neuroinflammation. Animal models have identified microglial priming as a major factor in a causal chain that leads to the wide spectrum of neuronal dysfunctions and behavioural phenotypes [59]. Increased head size in people with ASC correlates positively with a history of allergic/immune disorders [86]. In particular, there is an association between ASC and neuroinflammation in anterior regions of the neocortex $[79,101,110]$, resulting from activation of microglia and 
astrocytes [2]. Gene networks involved in immune processes are overexpressed in the brain of individuals with ASC [102, 103]. This has been linked to atypical expression of nuclear factor kappa-light-chain-enhancer of activated B cells $(\mathrm{NF}-\mathrm{kB})$ in a number of cell types in ASC including neurons, astrocytes, and microglia [107]. This has a linear relationship with $\mathrm{pH}$ changes localised to the lysosomal compartments of mature microglia [107], indicating increased immune activity. Microglia play a critical role in the pruning of synapses, thus providing a potential bridge between the atypical synaptic pruning and the immune dysregulatory hypotheses of ASC [78]. Below we review the mechanisms that may underlie neuroinflammation and the evidence at genetic and protein levels for each of these mechanisms (Table 1).

\section{Genetic studies}

Many loci have been implicated in the condition [42]. Most recently, a number of recent breakthroughs have dramatically advanced our understanding of ASC from the standpoint of human genetics and neuropathology. These studies highlight the period of foetal development and the processes of chromatin structure, synaptic function, and neuron-glial signalling [18]. A key component of genetic architecture is the allelic spectrum influencing trait variability. Recent studies have demonstrated that the total heritability of risk-associated genes is in the range of 50-60\% with common variants explaining the bulk of it [40]. In a comparison of genome-wide linkage studies between autoimmune and inflammatory disorders in ASC, overlap of polymorphic markers were statistically significant [8]. For a comprehensive list of the genes identified, see http://www.grc.nia.nih.gov/branches/rrb/dna/atsmap.htm.

Where it is conceded that the chromosomal regions identified in these linkage studies and the specific variants of genes identified in genetic association studies are quite often not unique to any one disorder [8]. Specific immunological genetic assays have been tested in panelled assays to test both sensitivity and specificity in diagnosing autism. Using a signature of differentially co-expressed genes that were enriched in translation and immune/inflammation

Table 1 Summary of contributing immunological factors in ASC

\begin{tabular}{|c|c|}
\hline $\begin{array}{l}\text { Level of biological } \\
\text { processes }\end{array}$ & Immunological factors involved \\
\hline Genetic & IFN- $\gamma$, Toll-like receptors, T-cell receptor \\
\hline Extracellular mediators & $\begin{array}{l}\text { Maternal antibodies, cytokines and } \\
\text { chemokines }\end{array}$ \\
\hline Cell surface proteins & $\begin{array}{l}\text { Human leukocyte antigen, Toll-like } \\
\text { receptors }\end{array}$ \\
\hline Intracellular signalling & mTOR, PTEN, NF-kB \\
\hline Neural changes & Neuron density, glial proliferation \\
\hline
\end{tabular}

function, the authors were able to identify boys with autism with $83 \%$ accuracy [85].

\section{Extracellular mediators Maternal-foetal transfer}

The involvement of an inflammatory pathogenesis in ASC likely originates during the gestational period [59]. Autoantibodies are transferred from the mother to the child during pregnancy and are associated with a number of factors that affect both pregnancy and neonatal outcome [100]. In a cohort of mothers of children with ASC, autoantibodies have been detected against critical neuronal components of foetal brain tissue samples [109] as well as transfer of maternal neuro-specific proteins [23]. These studies identified a range of unknown protein targets ranging from 30 to 250 kilodaltons $(\mathrm{kDa})$ in size. Consecutive independent studies have identified autoantibodies that bind to novel proteins of 37,39 , and $73 \mathrm{kDa}$ in size $[39,104]$.

A number of models have been hypothesised to explain the transfer of anti-foetal brain autoantibodies [58]. In one study, immunoglobulin G (IgG) isolated from mothers with children with ASC was transferred into rhesus macaque monkeys during mid-gestation and resulted in distinct behavioural changes in the offspring. In particular, the monkeys spent significantly less time in contact with their peers and spent more time in a nonsocial state. This was attributed to the specific IgG from mothers of children with ASC infusion and not observed in monkeys receiving IgG from control donors or monkeys that were saline treated $[7,65]$. These observations have been replicated in mice $[15,93]$. Whether the transfer of these auto-antibodies during gestation plays a role in the pathogenesis in ASC remains uncertain; however, it is clear that there is a potential association. Brimberg et al. [13] describes mothers of an ASC child being found to be four times more likely to harbour antibrain antibodies than other women of child-bearing age. Fundamentally, these processes may have a significant impact on neurodevelopment. Supporting this view is a recent study from Braunschweig et al. [11] who have identified that lactate dehydrogenases A and B (LDH), cypin, stress-induced phosphoprotein 1 (STIP1), collapsin response mediator proteins 1 and 2 (CRMP1, CRMP2), and Y-box-binding protein comprise the seven primary antigens of maternal autoantibody-related (MAR) autism. This built on previous work which introduced the concept of studying the maternal plasma antibodies against both the maternal and fatal brain [12, 24, 87].

A number of animal studies have demonstrated that placenta to foetus transport can alter development. Specifically, Lin et al. [63] used P. gingivalis in mice to demonstrate that maternal immune system stimulation can lead to elevated levels of pro-inflammatory cytokines in 
both the placenta and amniotic fluid, whilst at the same time decreasing the major anti-inflammatory cytokines TGF- $\beta$, IL-4, and IL-10. Maternal inoculation with Poly(I:C), as well as lipopolysaccharide (LPS), also in mice, have resulted in the animal displaying behavioural characteristics in keeping with ASC, including pre-pulse inhibition deficits, working memory deficits, and social interaction deficits [80]. Blocking the action of these pro-inflammatory cytokines during maternal infection was observed to inhibit the development of such behaviour [52, 80]. Maternal LPS administration upregulates both tumour necrosis factor-alpha (TNF- $\alpha$ ) and IL-1 $\beta$ mRNA expression in the foetuses of pregnant rats in a dose-dependent manner [38].

\section{Cytokines and chemokines}

Cytokines and chemokines are pleiotrophic proteins that coordinate the host response to infection as well as mediate normal, ongoing communication between cells of non-immune tissues, including the nervous system [27]. As a consequence of this dual role, cytokines induced in response to an adverse stimuli (i.e. maternal infection or prenatal hypoxia) can profoundly impact fetal neurodevelopment. Aberrant levels of proinflammatory cytokines, interleukin 6 (IL-6), TNF- $\alpha$ and monocyte chemotactic protein-1 (MCP-1), not only in brain specimens and cerebrospinal fluid (CSF; [90, 101]) but also in amniotic fluid [1], index an active inflammatory process both in children and adults with ASC. These molecules act to increase immune cell recruitment and proliferation. Immune pathways are activated by proinflammatory cytokines such as TNF- $\alpha$ and IL- 6 that stimulate the nuclear translocation of various transcription factors, including NF- $\kappa B$ that subsequently results in the potentiation of the immune response [81]. This is tightly controlled in acute infection and lasts for a limited time. However, the presence of such molecules in the absence of an acute stimulus is an atypical response. An atypical inflammatory response has been observed in peripheral samples to show similar changes [56] as well as decreases in anti-inflammatory protein IL10 [56]. In a larger multi-analyte profiling (MAP) analysis, Suzuki et al. [98] reported from a total of 48 analytes examined, the plasma concentrations of IL-1 $\beta$, IL-1RA, IL-5, IL-8, IL-12(p70), IL-13, IL-17, and growth regulated oncogene-alpha (GRO- $\alpha$ ) were significantly higher in individuals with ASC compared with the corresponding values of matched controls, after correction for multiple comparisons. Upregulation of inflammation-related molecules has also been found to be characteristic for adult males (but not females) with Asperger syndrome [95]. In midgestation maternal serum, elevated concentrations of IFN$\gamma$, IL-4, and IL-5 were significantly associated with a $50 \%$ increased risk of ASC, regardless of ASC onset type and the presence of intellectual disability [45].
The main issue surrounding the reporting of serum results is that they show considerable within- and between-group variability. As such, the subtle differences found may indicate the presence of separate subgroups of the condition [60]. For example, statistical clustering analysis on large-scale clinical data suggests the presence of subgroups with ASC characterised by co-occurrence of infectious disorder [31], which could be related to physiological atypicality related to inflammatory processes. Further analysis using appropriately powered studies will be required in order to gauge the potential explanatory power of this hypothesis.

\section{Cell surface proteins}

In contrast to cytokines and chemokines, major histocompatibility complex (MHC) family members have very short intracellular domains not thought to function in intracellular signalling cascades, but instead by interacting with a variety of receptors during cell-mediated immunity [92]. Together with TLRs, they form a key role in activity-dependent brain development and plasticity as well as regulating the immune response [84]. Specifically, it has been observed that (MHC) class I molecule $\mathrm{H} 2-\mathrm{D}(\mathrm{b})$ is essential for synapse elimination in the retinogeniculate system [62, 67].

Genetically, immune dysfunction in ASC has been suggested to included the MHC region, as this is an immunologic gene cluster whose gene products are class I, II, and III molecules. Class I and II molecules are associated with antigen presentation. The human leukocyte antigen (HLA) genes are among the strongest predictors of risk for autoimmune conditions. Some studies have observed that different HLA haplotypes are associated with neurodevelopmental conditions such as ASC $[19,55]$ and schizophrenia [94]. Stubbs et al. [97] initially demonstrated that mothers of children with ASC share HLA haplotypes with their children more often than in nonaffected pairs. Recent evidence has suggested that impairments of innate immunity, originating with cell surface proteins, may play an important role in ASC. Enstrom et al. [33] demonstrated an improved responsiveness to signalling via select TLRs: TLR 2 , TLR 4, and conversely a decreased production of cytokines following stimulation of TLR 9.

\section{Intracellular signalling pathways}

Another distinct pathway to be implicated in ASC is a well-known family of transcription factors, the nuclear factor kappa B (NF-kB), which is one of the key players in the regulation of inflammatory responses [77, 81]. This transcription factor is constitutively expressed in the cytoplasm and is inhibited by inhibitor $\kappa B(I \kappa B)$, which binds NF-kB, masking its nuclear localization signal and retaining it in the cytoplasm [44]. NF- $\kappa B$ activity 
is attributed to Rel/NF- $\mathrm{kB}$ family proteins forming homodimers and heterodimers through the combination of the subunits p65 (or RelA), p50, p52, c-Rel, or RelB [81]. Cytokines, chemokines, and reactive oxygen species are among a number of key mediators that induce NF- $\mathrm{kB}$ by activating ІкB kinases [77]. These phosphorylate ІкB $\alpha$, leading to its polyu biquitination and degradation [43], allow NF- $\mathrm{kB}$ to migrate to the nucleus, where it activates the transcription of various proinflammatory genes.

$\mathrm{NF}-\mathrm{kB}$ has been found to be aberrantly expressed in the orbitofrontal cortex in postmortem studies of adults with ASC [107]. Expression was most abundant in microglia followed by astrocytes compared to neurons. However, samples from other frontal lobe or cerebellar samples have not shown similar increases [64] suggesting a localisation of aberrant expression. Peripherally, NF- $\kappa B$ was upregulated in TNF- $\alpha$ and LPS stimulated peripheral blood monocytes (PBMCs) [71]. The upregulation of expression was found to be similar in that Young et al. [107] reported a 2.9-fold increase in NF-kB expression centrally compared to a 2.2 -fold increase reported peripherally [71]. The significance of this similarity is difficult to ascertain as there is significant heterogeneity of brain parenchyma in response to inflammatory stimuli [108]. The implication of the NF- $\mathrm{kB}$ signalling pathway in ASC further supports a potential role for neuroinflammation. Further work is needed to identify whether upregulation of NF- $\mathrm{kB}$ plays a role in initiating the signalling cascade or whether it is a result of aberrant stimulation.

\section{Neuroanatomical changes}

The ultrastructural morphology in ASC has been described as having atypical microglial and astroglial activation [101]. Prominent histological changes have been described in the cerebellum, characterised by a patchy loss of neurons in the Purkinje cell layer (PCL) and granular cell layer (GCL) [101] as well as a reduction in neuron number in the amygdalae and fusiform gyrus [89]. Glial activation has been widely observed throughout a number of independent studies. Vargas et al. [101] observed an increase in glial fibrillary acidic protein (GFAP) concentration in the white matter of the middle frontal gyrus (MFG) and anterior cingulate gyrus (ACG). An increased ratio of CD11c-positive, mature (highly active) microglia was observed in the orbitofrontal cortex and showed strong correlation with cell signalling molecules [107]. Microglial activation and increased microglial density was also observed in the dorsolateral prefrontal cortex in ASC [69]. Morphological alterations included somal enlargement, process retraction and thickening, and extension of filopodia from processes [69]. They also described a significant increase in microglial somal volume in the white matter. Microglial cell density was increased in the grey matter with non-significant trends in somal volume [69]. A recent study by Paolicelli and Gross [78] suggests a central role for microglia in synaptic pruning, a process that has been suggested to be aberrant in the developing brain in ASC [22].

Magnetic resonance spectroscopy (MRS) has provided significant insight into the ultrastructural morphology in ASC. Myo-inositol (Ins) is a metabolic compound located mostly in astrocytes. High Ins levels are thought to indicate an increase in astrocyte populations and are particularly abundant in neuroinflammation [10]. Interestingly, increased Ins levels have been demonstrated to impact on performance IQ scores in individuals with ASC [37].

The resonance group attributed to the glutamineglutamate-GABA complex (Glx) includes contributions from both glutamate and its precursor glutamine. Very little glutamate penetrates the blood-brain barrier, so local synthesis is essential. De novo synthesis is mediated mainly by astrocytes, and as such, in vivo levels can be altered in neuroinflammation [61]. Glutamate synthesised by astrocytes is converted to glutamine via the enzyme glutamine synthetase and exported to neurons via multiple transporters [26]. In neurons, glutamine is reconverted into glutamate using the mitochondrial enzyme phosphate-activated glutaminase and then packaged into synaptic vesicles for release [61]. Release of glutamate initiates signalling events in excitatory neurotransmission; transmission is terminated by the removal of glutamate from the extracellular space, predominantly via astrocytic glutamate transporters. This overall cycle of synthesis, release, and recovery of glutamate is referred to as the glutamate-glutamine cycle [50].

DeVito et al. [28] described widespread decrease in $\mathrm{N}$-acetylaspartate (NAA) and Glx among people with ASC, with reductions observed in both the cerebral grey matter and the cerebellum. In a sample of adults with ASC, there was also a significant decrease in concentration of Glx, as well as choline, creatine $(\mathrm{Cr})$ and NAA, in the basal ganglia [51]. A reduction in Glx would classically be attributed to a reduction in neuron density. Nevertheless, inflammatory molecules can also contribute to inhibiting the astrocytic glutamate reuptake [53] and by inducing changes in glutamate receptor subunit expression, thus leading to reduced intracellular levels of Glx [4].

\section{Specificity of neuroinflammation}

Neuroinflammation is emerging as a common finding in neurological and neuropsychiatric phenotypes. Most recently, it emerged as a finding in large genetic analyses of schizophrenia, bipolar disorder, and major depression [75]. This prompts the question of the specificity of inflammation as a contributing mechanism in the emergence of 
ASC. Furthermore, it promotes ongoing discussion on whether this is a causal or reactive process. What is certain is that, regardless of whether inflammation is specific to a condition or general to a majority of psychiatric conditions, if it is present, it should be treated and whether it forms part of a multisystme pathology, it should be treated and the response evaluated to observe whether there is a significant cognitive change. Clarifying the roles of various neuroinflammatory processes, causal (aetiological) or reactive, in neurodevelopmental conditions, also serves as a useful angle to delineate ubiquitous pathogenetic processes across all kinds of atypical neurodevelopment from specific mechanisms or reactive processes that mark one clinical diagnosis but not others.

\section{Evidence against inflammation as a contributing mechanism in autism}

There have been a few studies that failed to identify atypical inflammatory activity in ASC $[64,102]$. Voineagu et al. [102] detail that the immune changes observed in their study of convergent molecular pathology have a less pronounced genetic component and thus are most likely either secondary phenomena or caused by environmental factors. Some have even gone as far to say that there is evidence that the immune response is not overactivated [64]. Whilst these studies are important, they have not been replicated to the extent of papers supporting a role for inflammation in the pathogenesis of ASC. It is also important to consider that the scale of the inflammatory response is so vast that it is possible to target inflammatory mediators which may not contribute to the condition. This is well presented in a recent meta-analysis looking at the cytokine response in autism [66]. Where 19 cytokines were assessed, only 7 were observed to have significantly different levels in ASC.

\section{Conclusions}

An emerging focus of research into the aetiology of ASC has suggested neuroinflammation as one candidate underlying biological model. With over 1000 candidate genes associated with it, ASC has a strong genetic component [70]. Similar to most medical conditions, however, there is also a significant environmental component in place, through gene-environmental interplay such as epigenetic mechanisms. The study of inflammation in ASC provides an excellent opportunity to dissect potential gene-environmental interplay. Here, we have highlighted some of the common indications of immunological dysregulation as potential contributing pathogenic processes for, at least certain subgroups of, individuals with ASC. Nevertheless, it is unclear whether the role of inflammation in ASC induces epigenetic change, via the activation of signalling cascades, or whether it is a direct result of genetic mutation and downstream effects. Whilst there is a growing body of work to support the role of inflammation in ASC, the greatest area of weakness in the field is that in general, the findings tend to be from individual studies and rarely are these replicated. Future work is needed to demonstrate what are essentially preliminary findings in largescale studies. How much of a role, if any, neuroinflammation has on the emergence of ASC and contributing to its aetiological heterogeneity remains to be clarified.

\section{Abbreviations \\ ASC: autism spectrum condition; NF-KB: nuclear factor kappa-light-chain enhancer of activated B cells.}

\section{Competing interests}

The authors declare that they have no competing interests.

\section{Authors' contributions}

$\mathrm{AMHY}$ and DR performed the literature review, and AMHY wrote the manuscript. BC and MCL assisted with writing the manuscript and the provided continual supervision throughout the project. JS and SBC designed the study and provided overall supervision and final critical review of the manuscript. All authors read and approved the final manuscript.

\section{Acknowledgements}

SBC was supported by the MRC and the Autism Research Trust and M-CL by the William Binks Autism Neuroscience Fellowship, during the period of this work.

\section{Author details}

${ }^{1}$ Autism Research Centre, Department of Psychiatry, University of Cambridge, Douglas House, 18B Trumpington Road, Cambridge, UK. ${ }^{2}$ School of Clinical Medicine, Addenbrookes Hospital, University of Cambridge, Cambridge, UK. ${ }^{3}$ Centre for Integrative Neuroscience and Neurodynamics, School of Psychology and Clinical Language Science, University of Reading, Reading, UK. ${ }^{4}$ Centre for Addiction and Mental Health and Department of Psychiatry, University of Toronto, Toronto, Canada. ${ }^{5}$ Department of Psychiatry, National Taiwan University Hospital and College of Medicine, Taipei, Taiwan. ${ }^{6}$ Brain Mapping Unit, Department of Psychiatry, University of Cambridge,

Cambridge, UK. ${ }^{7}$ Behavioural and Clinical Neuroscience Institute, University of Cambridge, Cambridge, UK. ${ }^{8}$ CLASS Clinic, Cambridgeshire and Peterborough NHS Foundation Trust, Cambridge, UK.

Received: 25 September 2014 Accepted: 4 January 2016

Published online: 20 January 2016

\section{References}

1. Abdallah MW, Larsen N, Grove J, Bonefeld-Jørgensen EC, Nørgaard-Pedersen B, Hougaard DM, et al. Neonatal chemokine levels and risk of autism spectrum disorders: findings from a Danish historic birth cohort follow-up study. Cytokine. 2013;61(2):370-6. doi:10.1016/j.cyto.2012.11.015.

2. Anderson AA, Ushakov DS, Ferenczi MA, Mori R, Martin P, Saffell JL. Morphoregulation by acetylcholinesterase in fibroblasts and astrocytes. J Cell Physiol. 2008;215(1):82-100.

3. Ashwood P, Enstrom A, Krakowiak P, Hertz-Picciotto I, Hansen RL, Croen LA, et al. Decreased transforming growth factor beta1 in autism: a potential link between immune dysregulation and impairment in clinical behavioral outcomes. J Neuroimmunol. 2008;204(1-2):149-53.

4. Balosso S, Ravizza T, Pierucci M, Calcagno E, Invernizzi R, Di Giovanni G, et al. Molecular and functional interactions between tumor necrosis factor-alpha receptors and the glutamatergic system in the mouse hippocampus: implications for seizure susceptibility. Neuroscience. 2009;161(1):293-300.

5. Baron-Cohen S. The extreme male brain theory of autism. Trends Cogn Sci. 2002;6(6):248-54.

6. Baron-Cohen S, Leslie AM, Frith U. Does the autistic child have a "theory of mind"? Cognition. 1985;21(1):37-46.

7. Bauman MD, losif AM, Ashwood P, Braunschweig D, Lee A, Schumann CM, et al. Maternal antibodies from mothers of children with autism alter brain growth and social behavior development in the rhesus monkey. Transl Psychiatry. 2013;3:e278. doi:10.1038/tp.2013.47. 
8. Becker KG. Autism, asthma, inflammation, and the hygiene hypothesis. Med Hypotheses. 2007;69(4):731-40.

9. Beart PM, O'Shea RD. Transporters for L-glutamate: an update on their molecular pharmacology and pathological involvement. Br J Pharmacol. 2007;150(1):5-17.

10. Bernardi S, Anagnostou E, Shen J, Kolevzon A, Buxbaum JD, Hollander E, et al. In vivo $1 \mathrm{H}$-magnetic resonance spectroscopy study of the attentional networks in autism. Brain Res. 2011;1380:198-205.

11. Braunschweig D, Krakowiak P, Duncanson P, Boyce R, Hansen RL, Ashwood $P$, et al. Autism-specific maternal autoantibodies recognize critical proteins in developing brain. Transl Psychiatry. 2013;3:e277.

12. Braunschweig D, Ashwood P, Krakowiak P, Hertz-Picciotto I, Hansen R, Croen LA, et al. Autism: maternally derived antibodies specific for fetal brain proteins. Neurotoxicology. 2008;29(2):226-31.

13. Brimberg L, Sadiq A, Gregersen PK, Diamond B. Brain-reactive IgG correlates with autoimmunity in mothers of a child with an autism spectrum disorder. Mol Psychiatry. 2013;18(11):1171-7.

14. Buehler MR. A proposed mechanism for autism: an aberrant neuroimmune response manifested as a psychiatric disorder. Med Hypotheses. 2011;76(6):863-70.

15. Camacho J, Jones K, Miller E, Ariza J, Noctor S, Van de Water J, et al. Embryonic intraventricular exposure to autism-specific maternal autoantibodies produces alterations in autistic-like stereotypical behaviors in offspring mice. Behav Brain Res. 2014;266:46-51. doi:10.1016/j.bbr.2014.02.045.

16. Castedo M, Perfettini JL, Roumier T, Kroemer G. Cyclin-dependent kinase-1: linking apoptosis to cell cycle and mitotic catastrophe. Cell Death Differ. 2002;9(12):1287-93.

17. Chawarska K, Shic F, Macari S, Campbell DJ, Brian J, Landa R, et al. 18-month predictors of later outcomes in younger siblings of children with autism spectrum disorder: a baby siblings research consortium study. J Am Acad Child Adolesc Psychiatry. 2014;53(12):1317-27.

18. Chen JA, Peñagarikano O, Belgard TG, Swarup V, Geschwind DH. The emerging picture of autism spectrum disorder: genetics and pathology. Annu Rev Pathol. 2015;10:111-44.

19. Chien YL, Wu YY, Chen CH, Gau SS, Huang YS, Chien WH, et al. Association of HLA-DRB1 alleles and neuropsychological function in autism. Psychiatr Genet. 2012;22(1):46-9.

20. Clifford S, Dissanayake C, Bui QM, Huggins R, Taylor AK, Loesch DZ. Autism spectrum phenotype in males and females with fragile $X$ full mutation and premutation. J Autism Dev Disord. 2007;37(4):738-47.

21. Courchesne E, Campbell K, Solso S. Brain growth across the life span in autism: age-specific changes in anatomical pathology. Brain Res. 2011;1380:138-45.

22. Courchesne E, Mouton PR, Calhoun ME, Semendeferi K, Ahrens-Barbeau C, Hallet MJ, et al. Neuron number and size in prefrontal cortex of children with autism. JAMA. 2011;306(18):2001-10.

23. Croen LA, Goines P, Braunschweig D, Yolken R, Yoshida CK, Grether JK, et al. Brain-derived neurotrophic factor and autism: maternal and infant peripheral blood levels in the Early Markers for Autism (EMA) Study. Autism Res. 2008;1 (2):130-7.

24. Croen LA, Braunschweig D, Haapanen L, Yoshida CK, Fireman B, Grether JK, et al. Maternal mid-pregnancy autoantibodies to fetal brain protein: the early markers for autism study. Biol Psychiatry. 2008; 64(7):583-8.

25. Cusco I, Medrano A, Gener B, Vilardell M, Gallastegui F, Villa O, et al. Autismspecific copy number variants further implicate the phosphatidylinositol signaling pathway and the glutamatergic synapse in the etiology of the disorder. Hum Mol Genet. 2009:18(10):1795-804

26. Deitmer JW, Broer A, Broer S. Glutamine efflux from astrocytes is mediated by multiple pathways. J Neurochem. 2003:87(1):127-35.

27. Deverman BE, Patterson PH. Cytokines and CNS development. Neuron. 2009:64(1):61-78.

28. DeVito TJ, Drost DJ, Neufeld RW, Rajakumar N, Pavlosky W, Williamson P, et al. Evidence for cortical dysfunction in autism: a proton magnetic resonance spectroscopic imaging study. Biol Psychiatry. 2007;61 (4):465-73.

29. DSM-IV Sourcebook (1994) American Psychiatric Association. ISBN 978-0-89042-025-6.

30. DSM-V Sourcebook (2013) American Psychiatric Association. ISBN 978-0-89042-065-2

31. Doshi-Velez F, Ge Y, Kohane I. Comorbidity clusters in autism spectrum disorders: an electronic health record time-series analysis. Pediatrics. 2014;133(1):e54-63. doi:10.1542/peds.2013-0819.
32. Engstrom M, Karlsson R, Jonsson Jl. Inactivation of the forkhead transcription factor FoxO3 is essential for PKB-mediated survival of hematopoietic progenitor cells by kit ligand. Exp Hematol. 2003;31(4):316-23.

33. Enstrom AM, Onore CE, Van de Water JA, Ashwood P. Differential monocyte responses to TLR ligands in children with autism spectrum disorders. Brain Behav Immun. 2010;24(1):64-71.

34. Fatemi SH, Stary JM, Halt AR, Realmuto GR. Dysregulation of Reelin and Bcl-2 proteins in autistic cerebellum. J Autism Dev Disord. 2001:31(6):529-35.

35. Frith U. A new look at language and communication in autism. Br J Disord Commun. 1989;24(2):123-50.

36. Fujii E, Mori K, Miyazaki M, Hashimoto T, Harada M, Kagami S. Function of the frontal lobe in autistic individuals: a proton magnetic resonance spectroscopic study. J Med Invest. 2010;57(1-2):35-44.

37. Gabis L, Wei H, Azizian A, DeVincent C, Tudorica A, Kesner-Baruch Y, et al. $1 \mathrm{H}$-magnetic resonance spectroscopy markers of cognitive and language ability in clinical subtypes of autism spectrum disorders. J Child Neurol. 2008;23(7):766-74.

38. Gao YX, Cai FC. Experimental study on the therapeutic mechanism of high dose intravenous immunoglobulin in treatment of immune-mediated peripheral neuropathy. Zhonghua Er Ke Za Zhi. 2003;41(9):684-7.

39. Garty BZ, Ludomirsky A, Danon YL, Peter JB, Douglas SD. Placental transfer of immunoglobulin G subclasses. Clin Diagn Lab Immunol. 1994;1(6):667-9.

40. Gaugler T, Klei L, Sanders SJ, Bodea CA, Goldberg AP, Lee AB, et al. Most genetic risk for autism resides with common variation. Nat Genet. 2014;46(8):881-5.

41. Geschwind DH, Levitt P. Autism spectrum disorders: developmental disconnection syndromes. Curr Opin Neurobiol. 2007;17(1):103-11.

42. Geschwind DH, State MW. Gene hunting in autism spectrum disorder: on the path to precision medicine. Lancet Neurol. 2015;16.

43. Ghosh S, Karin M. Missing pieces in the NF-kappaB puzzle. Cell. 2002; 109(Suppl):S81-96.

44. Ghosh S, May MJ, Kopp EB. NF-kappa B and Rel proteins: evolutionarily conserved mediators of immune responses. Annu Rev Immunol. 1998;16:225-60.

45. Goines PE, Croen LA, Braunschweig D, Yoshida CK, Grether J, Hansen R, et al. Increased midgestational IFN-gamma, IL-4 and IL-5 in women bearing a child with autism: a case-control study. Mol Autism. 2011;2:13-2392-2-13.

46. Happé F, Frith U. The weak coherence account: detail-focused cognitive style in autism spectrum disorders. J Autism Dev Disord. 2006;36(1):5-25. Review.

47. Hay N, Sonenberg N. Upstream and downstream of mTOR. Genes Dev. 2004;18(16):1926-45

48. Herman GE, Butter E, Enrile B, Pastore M, Prior TW, Sommer A. Increasing knowledge of PTEN germline mutations: two additional patients with autism and macrocephaly. Am J Med Genet A. 2007;143(6):589-93.

49. Herman GE, Henninger N, Ratliff-Schaub K, Pastore M, Fitzgerald S, McBride KL. Genetic testing in autism: how much is enough? Genet Med. 2007;9(5):268-74.

50. Hertz $L$. The astrocyte-neuron lactate shuttle: a challenge of a challenge. J Cereb Blood Flow Metab. 2004;24(11):1241-8.

51. Horder J, Lavender T, Mendez MA, O'Gorman R, Daly E, Craig MC, et al. Reduced subcortical glutamate/glutamine in adults with autism spectrum disorders: a ['H]MRS study. Transl Psychiatry. 2013;3:e279.

52. Hsiao EY, McBride SW, Hsien S, Sharon G, Hyde ER, McCue T, et al. Microbiota modulate behavioral and physiological abnormalities associated with neurodevelopmental disorders. Cell. 2013;155(7):1451-63.

53. Hu S, Sheng WS, Ehrlich LC, Peterson PK, Chao CC. Cytokine effects on glutamate uptake by human astrocytes. Neuroimmunomodulation. 2000; 7(3):153-9.

54. Hu W, Zhang C, Wu R, Sun Y, Levine A, Feng Z. Glutaminase 2, a novel p53 target gene regulating energy metabolism and antioxidant function. Proc Natl Acad Sci U S A. 2010;107(16):7455-60.

55. Johnson WG, Buyske S, Mars AE, Sreenath M, Stenroos ES, Williams TA, et al. HLA-DR4 as a risk allele for autism acting in mothers of probands possibly during pregnancy. Arch Pediatr Adolesc Med. 2009;163(6):542-6.

56. Jyonouchi H, Sun S, Itokazu N. Innate immunity associated with inflammatory responses and cytokine production against common dietary proteins in patients with autism spectrum disorder. Neuropsychobiology. 2002;46(2):76-84.

57. Kern KL. The possible role of the cerebellum in autism/PDD: disruption of a multisensory feedback loop. Med Hypotheses. 2002;59(3):255-60.

58. Klauck SM. Genetics of autism spectrum disorder. Eur J Hum Genet. 2006; 14(6):714-20. 
59. Knuesel I, Chicha L, Britschgi M, Schobel SA, Bodmer M, Hellings JA, et al. Maternal immune activation and abnormal brain development across CNS disorders. Nat Rev Neurol. 2014;10(11):643-60.

60. Lai MC, Lombardo MV, Chakrabarti B, Baron-Cohen S. Subgrouping the autism "spectrum": reflections on DSM-5. PLoS Biol. 2013;11(4):e1001544.

61. Lee A, Pow DV. Astrocytes: glutamate transport and alternate splicing of transporters. Int J Biochem Cell Biol. 2010;42(12):1901-6.

62. Lee H, Brott BK, Kirkby LA, Adelson JD, Cheng S, Feller MB, et al. Synapse elimination and learning rules co-regulated by MHC class I H2-Db. Nature. 2014;509(7499):195-200.

63. Lin D, Smith MA, Champagne C, Elter J, Beck J, Offenbacher S. Porphyromonas gingivalis infection during pregnancy increases maternal tumor necrosis factor alpha, suppresses maternal interleukin-10, and enhances fetal growth restriction and resorption in mice. Infect Immun. 2003;71(9):5156-62.

64. Malik M, Tauqeer Z, Sheikh AM, Wen G, Nagori A, Yang K, et al. NF-kB signaling in the brain of autistic subjects. Mediators Inflamm. 2011; 2011:785265. doi:10.1155/2011/785265. Erratum in: Mediators Inflamm 2013:2013:691975

65. Martin LA, Ashwood P, Braunschweig D, Cabanlit M, Van de Water J, Amaral DG. Stereotypies and hyperactivity in rhesus monkeys exposed to IgG from mothers of children with autism. Brain Behav Immun. 2008; 22(6):806-16.

66. Masi A, Quintana DS, Glozier N, Lloyd AR, Hickie IB, Guastella AJ. Cytokine aberrations in autism spectrum disorder: a systematic review and metaanalysis. Mol Psychiatry. 2015;20(4):440-6.

67. McAllister AK. Major histocompatibility complex I in brain development and schizophrenia. Biol Psychiatry. 2014;75(4):262-8.

68. Mondino A, Mueller DL. mTOR at the crossroads of T cell proliferation and tolerance. Semin Immunol. 2007;19(3):162-72

69. Morgan JT, Chana G, Pardo CA, Achim C, Semendeferi K, Buckwalter J, et al. Microglial activation and increased microglial density observed in the dorsolateral prefrontal cortex in autism. Biol Psychiatry. 2010;68(4):368-76.

70. Murdoch JD, State MW. Recent developments in the genetics of autism spectrum disorders. Curr Opin Genet Dev. 2013;23(3):310-5.

71. Naik US, Gangadharan C, Abbagani K, Nagalla B, Dasari N, Manna SK. A study of nuclear transcription factor-kappa B in childhood autism. PLoS ONE. 2011;6(5):e19488.

72. Neuhaus E, Beauchaine TP, Bernier R. Neurobiological correlates of social functioning in autism. Clin Psychol Rev. 2010;30(6):733-48.

73. Nordahl CW, Lange N, Li DD, Barnett LA, Lee A, Buonocore MH, et al. Brain enlargement is associated with regression in preschool-age boys with autism spectrum disorders. Proc Natl Acad Sci U S A. 2011;108(50):20195-200. doi:10.1073/pnas.1107560108.

74. Nordahl CW, Scholz R, Yang X, Buonocore MH, Simon T, Rogers S, et al. Increased rate of amygdala growth in children aged 2 to 4 years with autism spectrum disorders: a longitudinal study. Arch Gen Psychiatry. 2012;69(1):53-61.

75. O'Dushlaine \& The Network and Pathway Analysis Subgroup of the Psychiatric Genomics Consortium. Psychiatric genome-wide association study analyses implicate neuronal, immune and histone pathways. Nat Neurosci. 2015;18:199-209.

76. Ozonoff S, Rogers SJ, Farnham JM, Pennington BF. Can standard measures identify subclinical markers of autism? J Autism Dev Disord. 1993;23(3):429-41.

77. Pahl HL. Activators and target genes of Rel/NF-kappaB transcription factors. Oncogene. 1999;18(49):6853-66.

78. Paolicelli RC, Gross CT. Microglia in development: linking brain wiring to brain environment. Neuron Glia Biol. 2011;7(1):77-83.

79. Pardo CA, Vargas DL, Zimmerman AW. Immunity, neuroglia and neuroinflammation in autism. Int Rev Psychiatry. 2005;17(6):485-95.

80. Patterson $\mathrm{PH}$. Immune involvement in schizophrenia and autism: etiology, pathology, and animal models. Behav Brain Res. 2008;12:121-8.

81. Perkins ND. NF-kappaB: tumor promoter or suppressor? Trends Cell Biol. 2004;14(2):64-9.

82. Plaisted K, O'Riordan M, Baron-Cohen S. Enhanced visual search for a conjunctive target in autism: a research note. J Child Psychol Psychiatry. 1998;39:777-83.

83. Plaisted K, O'Riordan M, Baron-Cohen S. Enhanced discrimination of novel, highly similar stimuli by adults with autism during a perceptual learning task. J Child Psychol Psychiatry. 1998:39:765-75.

84. Prabowo AS, lyer AM, Anink JJ, Spliet WG, Rijen PC, Aronica E. Differential expression of major histocompatibility complex class I in developmental glioneuronal lesions. J Neuroinflammation. 2013;10:12.
85. Pramparo T, Pierce K, Lombardo MV, Carter Barnes C, Marinero S, AhrensBarbeau $\mathrm{C}$, et al. Prediction of autism by translation and immune/ inflammation coexpressed genes in toddlers from pediatric community practices. JAMA Psychiatry. 2015;72(4):386-94.

86. Sacco R, Militerni R, Frolli A, Bravaccio C, Gritti A, Elia M, et al. Clinical, morphological, and biochemical correlates of head circumference in autism. Biol Psychiatry. 2007;62(9):1038-47.

87. Sadiq FA, Slator L, Skuse D, Law J, Gillberg C, Minnis H. Social use of language in children with reactive attachment disorder and autism spectrum disorders. Eur Child Adolesc Psychiatry. 2012;21(5):267-76.

88. Sauer S, Bruno L, Hertweck A, Finlay D, Leleu M, Spivakov M, et al. T cell receptor signaling controls Foxp3 expression via PI3K, Akt, and mTOR. Proc Natl Acad Sci U S A. 2008:105(22):7797-802.

89. Schumann CM, Nordahl CW. Bridging the gap between MRI and postmortem research in autism. Brain Res. 2011:1380:175-86.

90. Schwarz E, Guest PC, Rahmoune H, Wang L, Levin Y, Ingudomnukul E, et al. Sex-specific serum biomarker patterns in adults with Asperger's syndrome. Mol Psychiatry. 2011;16(12):1213-20.

91. Shin JW, Nguyen KT, Pow DV, Knight T, Buljan V, Bennett MR, et al. Distribution of glutamate transporter GLAST in membranes of cultured astrocytes in the presence of glutamate transport substrates and ATP. Neurochem Res. 2009;34(10):1758-66.

92. Shatz CJ. MHC class I: an unexpected role in neuronal plasticity. Neuron. 2009;64(1):40-5.

93. Singer HS, Morris C, Gause C, Pollard M, Zimmerman AW, Pletnikov M. Prenatal exposure to antibodies from mothers of children with autism produces neurobehavioral alterations: a pregnant dam mouse model. J Neuroimmunol. 2009:211(1-2):39-48

94. Singh B, Bera NK, De S, Nayak C, Chaudhuri TK. Study of HLA class I gene in Indian schizophrenic patients of Siliguri, West Bengal. Psychiatry Res. 2011;189(2):215-9.

95. Steeb H, Ramsey JM, Guest PC, Stocki P, Cooper JD, Rahmoune H, et al. Serum proteomic analysis identifies sex-specific differences in lipid metabolism and inflammation profiles in adults diagnosed with Asperger syndrome. Mol Autism. 2014;5(1):4. doi:10.1186/2040-2392-5-4.

96. Stubbs EG, Budden SS, Jackson RH, Terdal LG, Ritvo ER. Effects of fenfluramine on eight outpatients with the syndrome of autism. Dev Med Child Neurol. 1986;28(2):229-35.

97. Stubbs EG, Ritvo ER, Mason-Brothers A. Autism and shared parental HLA antigens. J Am Acad Child Psychiatry. 1985;24(2):182-5.

98. Suzuki K, Matsuzaki H, Iwata K, Kameno Y, Shimmura C, Kawai S, et al. Plasma cytokine profiles in subjects with high-functioning autism spectrum disorders. PLoS ONE. 2011;6(5):e20470.

99. Tabuchi K, Blundell J, Etherton MR, Hammer RE, Liu X, Powell CM. A neuroligin-3 mutation implicated in autism increases inhibitory synaptic transmission in mice. Science. 2007;318:71-6.

100. Tincani A, Rebaioli CB, Frassi M, Taglietti M, Gorla R, Cavazzana I, et al. Pregnancy and autoimmunity: maternal treatment and maternal disease influence on pregnancy outcome. Autoimmun Rev. 2005;4(7): 423-8.

101. Vargas DL, Nascimbene C, Krishnan C, Zimmerman AW, Pardo CA. Neuroglial activation and neuroinflammation in the brain of patients with autism. Ann Neurol. 2005:57(1):67-81.

102. Voineagu I, Wang $X$, Johnston $P$, Lowe JK, Tian $Y$, Horvath $S$, et al. Transcriptomic analysis of autistic brain reveals convergent molecular pathology. Nature. 2011;474(7351):380-4.

103. Voineagu I, Eapen V. Converging pathways in autism spectrum disorders: interplay between synaptic dysfunction and immune responses. Front Hum Neurosci. 2013:7:738

104. Warren RP, Cole P, Odell JD, Pingree CB, Warren WL, White E, et al. Detection of maternal antibodies in infantile autism. J Am Acad Child Adolesc Psychiatry. 1990;29(6):873-7.

105. Williams PG, Hersh JH. Brief report: the association of neurofibromatosis type 1 and autism. J Autism Dev Disord. 1998;28(6):567-71.

106. Wiznitzer M. Autism and tuberous sclerosis. J Child Neurol. 2004;19(9):675-9.

107. Young AM, Campbell E, Lynch S, Suckling J, Powis SJ. Aberrant NF-kappaB expression in autism spectrum condition: a mechanism for neuroinflammation. Front Psychiatry. 2011;2:27.

108. Young AM, Campbell E, Lynch S, Dunn M, Powis SJ. TNF-a induction of murine brain inflammation via IKK/NF kappa B signalling: a potential model for autism. PLOS ONE. 2012;7(6):e39049. 
109. Zimmerman AW, Connors SL, Matteson KJ, Lee LC, Singer HS, Castaneda JA, et al. Maternal antibrain antibodies in autism. Brain Behav Immun. 2007; 21(3):351-7.

110. Zimmerman AW, Jyonouchi H, Comi AM, Connors SL, Milstien S, Varsou A, et al. Cerebrospinal fluid and serum markers of inflammation in autism. Pediatr Neurol. 2005:33(3):195-201.

Submit your next manuscript to BioMed Central and we will help you at every step:

- We accept pre-submission inquiries

- Our selector tool helps you to find the most relevant journal

- We provide round the clock customer support

- Convenient online submission

- Thorough peer review

- Inclusion in PubMed and all major indexing services

- Maximum visibility for your research

Submit your manuscript at www.biomedcentral.com/submit 